\title{
Nitrogen fertilization of dryland grasses in the Northern Great Plains
}

\author{
J.S. JACOBSEN, S.H. LORBEER, H.A.R. HOULTON, AND G.R. CARLSON
}

\begin{abstract}
Authors are extension soil scientist and associate professor, research associate, Montana State University. Bozeman, Mont., associate professor (deceased) and associate professor, Northern Agricultural Research Center, Havre, Mont.
\end{abstract}

\begin{abstract}
Dryland grass production is an important agricultural commodity in the Northern Great Plains. Nitrogen (N) fertilizer can increase dry matter production and forage quality, yet there are relatively few rangeland and improved pasture managers who utilize fertilization practices to optimize production. Two trials (1972-1975 and 1978-1981) with 10 common grass species used a single application of 0,56 , or $112 \mathrm{~kg} \mathrm{~N} \mathrm{ha}^{-1}$ and 0,112 , or $224 \mathrm{~kg}$ $\mathrm{N} \mathrm{ha}^{-1}$ to evaluate long-term grass performance to $\mathrm{N}$ fertilization. Dry matter production in each trial was measured annually for 4 years. Yields increased on average $1,340 \mathrm{~kg} \mathrm{ha}^{-1}$ with the application of $56 \mathrm{~kg} \mathrm{~N} \mathrm{ha}^{-1}$, and $1,662 \mathrm{~kg} \mathrm{ha}^{-1}$ with $112 \mathrm{~kg} \mathrm{~N} \mathrm{ha}^{-1}$ in Trial 1. In Trial 2, yields increased 3,499 and $5,140 \mathrm{~kg} \mathrm{ha}^{-1}$ with applications of 112 and $224 \mathrm{~kg} \mathrm{~N}^{-1}$, respectively. Responses to applied $\mathbf{N}$ were evident $\mathbf{4}$ years after application for some species, most likely due to the combination of improved grass vigor and recycling of fertilizer $\mathbf{N}$ immobilized in organic forms. Single applications of $\mathbf{N}$ were effective in improving dry matter production of some common grasses for multiple years, when water was suitable. The magnitude of response and potential economic return from fertilization were species dependent.
\end{abstract}

Key Words: seeded grass, forage production, management, fertilizer use efficiency, precipitation use efficiency

Forage grass is produced on approximately $52 \%$ of the 141 million hectares in the Northern Great Plains (Kan., Mont., N.D., Neb., S.D., Wyo.; Daugherty 1991). Species composition, plant available nutrients and water, climate, and other agronomic factors influence production and quality characteristics. The application of fertilizer nitrogen $(\mathrm{N})$ to grasses is a key management tool for increased production if soil fertility levels are less than optimum, economics are favorable, and the environment will not be adversely impacted. Many studies have shown a doubling or more of dry matter yields from fertilizer $\mathrm{N}$ application (Kilcher 1958, Black 1968, McGinnies 1968, Power and Alessi 1971, Wight and Black 1979, Read and Winkleman 1982, Power 1985).

Fairway crested wheatgrass [Agropyron cristatum (L.) Gaertn.], intermediate wheatgrass [Thinopyrum intermedium (Host) Barkw. \& D.R. Dewey ssp. intermedium], and Russian wildrye

Contribution No. J-2971 from the Montana Agr. Exp. Sta. and Ext. Serv., Bozeman, Mont.

Accepted 20 Sep 1995.
[Psathyrostachys juncea (Fisch.) Nevski] responded to annual N fertilization (Kilcher 1958). In the unfertilized checks, intermediate wheatgrass out produced fairway crested wheatgrass and Russian wildrye. However, fairway crested wheatgrass out produced intermediate wheatgrass at higher $\mathrm{N}$ levels. Russian wildrye did not yield as much as either of the wheatgrasses following $\mathrm{N}$ application, although its proportionate yield increase was greater than that of intermediate whentgrass. Largest yields were obtained when precipitation, particularly in May, was adequate.

Power (1985) conducted a 9-year study at Mandan, N.D. on 10 seeded perennial grasses which received annual applications of 0 , 45 , and $225 \mathrm{~kg} \mathrm{~N} \mathrm{ha}^{-1}$. Greatest yields usually occurred in wettest years, and least during dry periods. All grasses responded to increasing $\mathrm{N}$ fertilization with several exceptions in the driest year. Similar results were obtained on range vegetation by Johnston et al. (1969). Furthermore, Power (1985) found that compared to the check, average dry matter production for most species at least doubled with the annual addition of $45 \mathrm{~kg} \mathrm{~N} \mathrm{ha}^{-1}$, and increased 3 to 4 -fold with $225 \mathrm{~kg} \mathrm{~N} \mathrm{ha}^{-1}$ applied annually. Intermediate wheatgrass [Thinopyrum intermedium (Host) Barkw. \& D.R. Dewey ssp. intermedium] produced the most dry matter (9-year cumulative yield), followed by crested wheatgrass [Agropyron desertorum (Fisch. ex Link) Schult.], western wheatgrass [Pascopyrum smithii (Rydb.)A. Löve], and green needlegrass [Stipa viridula Trin.], with Russian wildrye [Psathyrostachys juncea (Fisch.) Nevski] and Garrison creeping foxtail (Alopecurus arundinaceus Poir) producing the least.

A 6-year study in North Dakota was conducted on native range (western wheatgrass [Pascopyrum smithii (Rydb.)A. Löve], blue grama [Bouteloua gracilis, (Kunth) Lag. Ex. Steud], and threadleaf sedge [Carex filifolia, Nutt.]). The same total amount of $\mathrm{N}$ fertilizer was applied either as a single application at study initiation, in 3 equal applications during the first 3 years, or in 6 equal annual applications (Power and Alessi 1971). Rates included 0, $34,68,135,270$, and $540 \mathrm{~kg} \mathrm{~N}^{-1}$. The study found that timing of application did not influence total production, and total production increased with $\mathbf{N}$ application. Since a single $\mathbf{N}$ fertilizer application increased production for multiple years, the additional time and expense of smaller annual applications may not be warranted.

Mason and Miltimore (1972) applied single applications of ammonium nitrate at 12 rates to a natural cover of beardless 
Table 1. Common dryland grasses in these studies.

\begin{tabular}{lll}
\hline \hline Common Name & Scientific Name & Variety \\
\hline Basin wildrye & Elymus cinereus (Scribn. \& Merr.) A. Löve & Plant Materials Center \\
Beardless wheatgrass & Agropyron inerme (Scrib. and Smith) Rydb. & Whitman \\
Crested wheatgrass & Agropyron desertorum (Fisch. ex Link) Schult. & Standard \\
Green needlegrass & Stipa viridula Trin. & PM-M-600, Plant \\
& & Materials Center \\
Intermediate wheatgrass & Thinopyrum intermedium (Host) Barkw. \& D.R. Dewey ssp. intermedium & Greenar \\
Intermediate wheatgrass & Thinopyrum intermedium (Host) Barkw. \& D.R. Dewey ssp. intermedium & Oahe \\
Pubescent wheatgrass & Thinopyrum intermedium (Host) Barkw. \& & Mandan 759 \\
& D.R. Dewey ssp. barbulatum (Schur) Barkw. \& D.R. Dewey & Vinall \\
Russian wildrye & Psathyrostachys juncea (Fisch.) Nevski & Havre \\
Thickspike wheatgrass & Elymus lanceolatus (Scribn. \& J.G. Smith) Gould & Unknown \\
Western wheatgrass & Pascopyrum smithii (Rydb.) A. Löve &
\end{tabular}

wheatgrass [Agropyron inerme (Scrib. and Smith) Rydb.], sandberg bluegrass [Poa secunda, Presl.], and big sagebrush [Artemisia tridentata, Nutt.], after removing the sagebrush by mowing. They found that considerable increases in yield were obtained over the 10 -year study period from a single $\mathrm{N}$ application, particularly for the higher fertilization levels, up to $504 \mathrm{~kg} \mathrm{~N}$ $\mathrm{ha}^{-1}$. In another 10-year study, single applications of $0,50,100$, 400 , and $800 \mathrm{~kg} \mathrm{~N} \mathrm{ha}^{-1}$ were applied to old stands of fairway crested wheatgrass [Agropyron cristatum (L.) Gaertn.] and production increased with the magnitude of response increasing with applied N (Read and Winkleman 1982). Even at low rates, applied $\mathrm{N}$ enhanced growth for several years.

Lutwick and Smith (1979) conducted a 5-year trial on several perennial grasses. Highest unfertilized 5-year cumulative yields were produced by intermediate wheatgrass [Thinopyrum intermedium (Host) Barkw. \& D.R. Dewey ssp. intermedium], followed in order by western wheatgrass [Pascopyrum smithii (Rydb.)A. Löve] and fairway crested wheatgrass [Agropyron cristatum (L.) Gaertn.] and then Russian wildrye [Psathyrostachys juncea (Fisch.) Nevski]. After a single application of $\mathrm{N}$ fertilizer, cumulative 3-year yields responded proportionately greater, with the exception of fairway crested wheatgrass which out produced western wheatgrass.

By applying ${ }^{15} \mathrm{~N}$ labeled fertilizer to crested wheatgrass [Agropyron desertorum (Fisch. ex Link) Schult.], Smith and Power (1985) determined the sequential fate and behavior of applied $\mathrm{N}$ for 5 years. Most residual $\mathrm{N}$ became incorporated in organic form each season, with relatively little left in the ammonium or nitrate forms. However, the newly formed organic $N$ was 3 to 10 times more susceptible to mineralization than the soil $\mathrm{N}$.

Grass production is clearly a significant contributor to livestock enterprises and local and export markets. Recent trends, including potential increases in public land grazing fees, land use restrictions and expiration of Conservation Reserve Program (CRP) contracts may force producers and ranchers to rethink their grass production strategy. Although several grass species are available for seeding, $\mathrm{N}$ fertilizer research on the wide range of grass species is limited in the Northern Great Plains. These studies were conducted to help understand the relationship between numerous common grass species, their multi-year responses to a single application of $\mathrm{N}$ fertilizer, and their efficiency response to fertilizer $\mathrm{N}$ and precipitation.

\section{Materials and Methods}

Ten grass species (Table 1) were seeded in randomized complete block designs in the early spring of 1971 and 1977 at the Northern Agricultural Research Center (48 $30^{\prime} \mathrm{N} ; 109^{\circ} 47^{\prime}$ $30^{\prime \prime} \mathrm{W}$ ) outside Havre, Mont. The sites were broken out of native sod in 1915, and have been used in a wide range of crop research projects since then. Both trials were planted on fine-loamy, mixed, Aridic Argiborolls. The first trial (Trial 1) site is comprised of Chinook Fine Sandy Loam-2-4\% slopes and TelstadJoplin-Kevin loams-2-4\% slopes, whereas the second trial (Trial 2) site was planted on Telstad-Joplin-Kevin loams-2-4\% slopes.

Prior to seeding, the site of Trial 1 had been fallowed for 2 years following several years of cereal-fallow rotation. Prior to seeding, the site of Trial 2 had been in introduced grasses for many years, and was plowed and fallowed in preparation for seeding. Species were selected from commonly used grasses in the Northern Great Plains. Grasses were seeded in 1.8 by $3.7 \mathrm{~m}$ plots with $0.36 \mathrm{~m}$ row spacing with 2 replications. Nitrogen fertilizer (34-0-0) at 0,56 , and $112 \mathrm{~kg} \mathrm{~N} \mathrm{ha}^{-1}$ for Trial 1 and 0,112 , and $224 \mathrm{~kg} \mathrm{~N} \mathrm{ha}^{-1}$ for Trial 2 was broadcast in late fall of 1971 and 1977 after grass establishment. No additional fertilizer was applied. Full stands were obtained for all grasses.

Grasses were harvested as individual species matured. Trial 1 grasses were hand clipped from 2 subsamples of $1 \mathrm{~m}^{2}$ at a $2.5 \mathrm{~cm}$ cutting height. Trial 2 grasses were mechanically harvested from two 0.6 by $3.1 \mathrm{~m}$ areas. Cutting height was $3.8 \mathrm{~cm}$ in years 1 to 3 , and $5.1 \mathrm{~cm}$ in year 4 . Samples were dried $\left(40^{\circ} \mathrm{C}\right)$ and weighed each year for 4 years. Standard ANOVA and regression analysis were performed. Means were separated using the protected LSD (Snedecor and Cochran 1980).

\section{Results and Discussion}

\section{Cumulative Yields of 10 Grasses}

The average 4-year cumulative dry matter yield of 10 species over 2 trials showed that a single $112 \mathrm{~kg} \mathrm{~N}^{-1}$ application (similar rate for both trials) increased production over the check from 5,143 to $7,723 \mathrm{~kg} \mathrm{ha}^{-1}$. Trials 1 and 2 varied considerably in the 4year cumulative check production, chiefly due to differences in amount and timing of precipitation (Table 2). In Trial 1, with 112 
Table 2. Precipitation records for Trials 1 and 2.

\begin{tabular}{|c|c|c|c|c|}
\hline \multirow[b]{2}{*}{ Study year } & \multicolumn{3}{|c|}{ Month } & \multirow[b]{2}{*}{ Annual $^{1}$} \\
\hline & April & May & June & \\
\hline - & \multicolumn{4}{|c|}{ 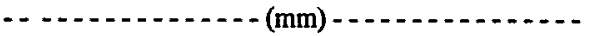 } \\
\hline 1 & 21 & 28 & 14 & 293 \\
\hline 2 & 62 & 22 & 94 & 290 \\
\hline 3 & 23 & 156 & 8 & 416 \\
\hline 4 & 73 & 54 & 80 & 488 \\
\hline \multicolumn{5}{|l|}{ Trial 2} \\
\hline 1 & 44 & 84 & 28 & 426 \\
\hline 2 & 41 & 25 & 38 & 274 \\
\hline 3 & 35 & 44 & 89 & 253 \\
\hline 4 & 0 & 88 & 38 & 327 \\
\hline 30 yr avg 2 & 25 & 43 & 56 & 282 \\
\hline
\end{tabular}

1 Oct. to 30 Sept.

2 MAPS (Caprio et al. 1994)

$\mathrm{kg} \mathrm{N} \mathrm{ha-1}$, average yield increased $1,661 \mathrm{~kg} \mathrm{ha}^{-1}$ from the check yield of $6,030 \mathrm{~kg} \mathrm{ha}^{-1}$, and Trial 2, average yield increased 3,499 $\mathrm{kg} \mathrm{ha}^{-1}$ from the check yield of $4,256 \mathrm{~kg} \mathrm{ha}^{-1}$.

\section{Annual Production}

Total precipitation during Trial $2(1,280 \mathrm{~mm})$ was less than that for Trial $1(1,487 \mathrm{~mm})$, but cumulative grass production increased, which on the surface would not be expected in semiarid environments. However, for both trials, average annual pre- cipitation was above normal for the area. The yearly production averages (of 10 species) offer an explanation. In the first year of Trial 1, only a $156 \mathrm{~kg} \mathrm{ha}^{-1}$ increase over check was produced with $112 \mathrm{~kg} \mathrm{~N} \mathrm{ha}^{-1}$, due to little precipitation (Tables 2 and 3). In contrast, Trial 2 started with a wetter than average first year, and production over the check averaged $2,379 \mathrm{~kg} \mathrm{ha}^{-1}$ with $112 \mathrm{~kg} \mathrm{~N} \mathrm{ha}^{-1}$ (Tables 2 and 4).

Although in the second year of Trial 1 total precipitation was similar to that for the first year, spring precipitation was much greater than the second year, producing a $673 \mathrm{~kg} \mathrm{ha}^{-1}$ increase over the check. For Trial 2, the second year was drier than the first, and the spring was drier than average. Average production over check fell to $817 \mathrm{~kg} \mathrm{ha}^{-1}$. In years 3 and 4 , Trial 1 received more precipitation than average. During this period, Trial 1 had greater $\mathrm{N}$ response than Trial 2, but not enough to make up for the superior performance during year 1 of Trial 2.

Similar to results of Power and Alessi (1971), Mason and Miltimore (1972), and Read and Winkleman (1982), these trials demonstrate how a single $\mathrm{N}$ application can boost yields for several years. If growing conditions are poor during the first year (year of application), residual $\mathrm{N}$ can remain in the soil/plant system and increase production in subsequent years as observed by Smith and Power (1985). Grass vigor may also be increased which could carry-over into later years.

An essential difference between Trial 1 and Trial 2 was precipitation quantity, especially during the year in which fertilizers

Table 3. Dry matter production in Trial 1 for 10 grass species.

\begin{tabular}{|c|c|c|c|c|c|c|c|}
\hline \multirow[b]{2}{*}{ Species } & \multirow[b]{2}{*}{ N rate } & \multicolumn{4}{|c|}{ Year } & \multirow{2}{*}{\multicolumn{2}{|c|}{ Cumulative }} \\
\hline & & 1 & 2 & 3 & $\overline{4}$ & & \\
\hline Basin wildrye & $\begin{array}{c}0-- \\
0 \\
56 \\
112\end{array}$ & $\begin{array}{l}506 \mathrm{a}^{\mathrm{l}} \\
592 \mathrm{ab} \\
643 \mathrm{~b}\end{array}$ & $\begin{array}{l}1364 a \\
1498 \text { a } \\
1758 \text { a }\end{array}$ & $\begin{array}{l}1795 \mathrm{a} \\
2371 \mathrm{a} \\
2369 \mathrm{a}\end{array}$ & $\begin{array}{l}1711 \mathrm{a} \\
2001 \mathrm{a} \\
1955 \mathrm{a}\end{array}$ & $\begin{array}{l}5376 a \\
6462 \mathrm{a} \\
6725 \mathrm{a}\end{array}$ & $\begin{array}{l}A B C^{2} \\
A B C \\
B\end{array}$ \\
\hline Beardless wheatgrass & $\begin{array}{r}0 \\
56 \\
112\end{array}$ & $\begin{array}{l}591 \mathrm{a} \\
822 \mathrm{a} \\
791 \mathrm{a}\end{array}$ & $\begin{array}{l}1486 a \\
1386 a \\
1456 a\end{array}$ & $\begin{array}{l}1287 \mathrm{a} \\
1552 \mathrm{a} \\
1657 \mathrm{a}\end{array}$ & $\begin{array}{l}1198 \mathrm{a} \\
1444 \mathrm{a} \\
1436 \mathrm{a}\end{array}$ & $\begin{array}{l}4562 \text { a } \\
5204 \text { a } \\
5341 \text { a }\end{array}$ & $\begin{array}{l}\text { A } \\
\text { A } \\
\text { A }\end{array}$ \\
\hline Crested wheatgrass & $\begin{array}{r}0 \\
56 \\
112\end{array}$ & $\begin{array}{l}1370 \mathrm{a} \\
1267 \mathrm{a} \\
1280 \mathrm{a}\end{array}$ & $\begin{array}{l}2534 \mathrm{a} \\
3058 \mathrm{ab} \\
3573 \mathrm{~b}\end{array}$ & $\begin{array}{l}1720 a \\
2469 a \\
2420 a\end{array}$ & $\begin{array}{l}1355 \mathrm{a} \\
1645 \mathrm{a} \\
1521 \mathrm{a}\end{array}$ & $\begin{array}{l}6979 a \\
8439 b \\
8793 b\end{array}$ & $\begin{array}{l}\mathrm{CD} \\
\mathrm{BCD} \\
\mathrm{DE}\end{array}$ \\
\hline Green needlegrass & $\begin{array}{r}0 \\
56 \\
112\end{array}$ & $\begin{array}{l}733 \mathrm{a} \\
945 \mathrm{~b} \\
982 \mathrm{~b}\end{array}$ & $\begin{array}{l}2775 \mathrm{a} \\
2728 \mathrm{a} \\
3062 \mathrm{a}\end{array}$ & $\begin{array}{l}1851 \mathrm{a} \\
2084 \mathrm{a} \\
2111 \mathrm{a}\end{array}$ & $\begin{array}{l}1362 \mathrm{a} \\
1458 \mathrm{a} \\
1557 \mathrm{a}\end{array}$ & $\begin{array}{l}6720 a \\
7215 a \\
7713 a\end{array}$ & $\begin{array}{l}C D \\
A B C \\
C\end{array}$ \\
\hline $\begin{array}{l}\text { Intermediate wheatgrass } \\
\text { 'Greenar' }\end{array}$ & $\begin{array}{r}0 \\
56 \\
112\end{array}$ & $\begin{array}{l}1099 \mathrm{a} \\
1120 \mathrm{a} \\
1268 \mathrm{a}\end{array}$ & $\begin{array}{l}2918 \mathrm{a} \\
3431 \mathrm{~b} \\
3836 \mathrm{c}\end{array}$ & $\begin{array}{l}1956 \mathrm{a} \\
2495 \mathrm{~b} \\
2597 \mathrm{~b}\end{array}$ & $\begin{array}{l}1496 \mathrm{a} \\
1799 \mathrm{ab} \\
2003 \mathrm{~b}\end{array}$ & $\begin{array}{l}7469 a \\
8844 b \\
9704 c\end{array}$ & $\begin{array}{l}D \\
C D \\
E\end{array}$ \\
\hline $\begin{array}{l}\text { Intermediate wheatgrass } \\
\text { 'Oahe' }\end{array}$ & $\begin{array}{r}0 \\
56 \\
112\end{array}$ & $\begin{array}{l}1392 \mathrm{a} \\
1533 \mathrm{a} \\
1708 \mathrm{a}\end{array}$ & $\begin{array}{l}2863 a \\
3751 b \\
4426 b\end{array}$ & $\begin{array}{l}1574 \mathbf{a} \\
2729 \mathbf{a} \\
2787 \mathrm{a}\end{array}$ & $\begin{array}{l}1515 a \\
2130 a \\
1962 a\end{array}$ & $\begin{array}{r}7343 a \\
10140 a \\
10880 a\end{array}$ & $\begin{array}{l}\mathrm{D} \\
\mathrm{D} \\
\mathrm{F}\end{array}$ \\
\hline Pubescent wheatgrass & $\begin{array}{r}0 \\
56 \\
112\end{array}$ & $\begin{array}{l}1063 a \\
1457 a \\
1433 a\end{array}$ & $\begin{array}{l}2565 \mathrm{a} \\
3696 \mathrm{~b} \\
3823 \mathrm{~b}\end{array}$ & $\begin{array}{l}1123 \mathrm{a} \\
2283 \mathrm{a} \\
1834 \mathrm{a}\end{array}$ & $\begin{array}{l}1306 a \\
1639 a \\
1283 a\end{array}$ & $\begin{array}{l}6057 a \\
9074 a \\
8374 a\end{array}$ & $\begin{array}{l}A B C D \\
C D \\
C D\end{array}$ \\
\hline Russian wildrye & $\begin{array}{r}0 \\
56 \\
112\end{array}$ & $\begin{array}{l}676 a \\
694 a \\
642 a\end{array}$ & $\begin{array}{l}2019 a \\
2422 b \\
2702 b\end{array}$ & $\begin{array}{l}1027 \text { a } \\
1599 \text { a } \\
1494 a\end{array}$ & $\begin{array}{l}1064 \mathrm{a} \\
1265 \mathrm{a} \\
1267 \mathrm{a}\end{array}$ & $\begin{array}{l}4785 a \\
5980 a \\
6105 a\end{array}$ & $\begin{array}{l}A B \\
A B \\
A B\end{array}$ \\
\hline Thickspike wheatgrass & $\begin{array}{r}0 \\
56 \\
112\end{array}$ & $\begin{array}{r}824 a \\
818 a \\
1011 a\end{array}$ & $\begin{array}{l}2116 a \\
2190 a \\
2639 b\end{array}$ & $\begin{array}{l}1706 \mathrm{a} \\
1794 \mathrm{a} \\
1949 \mathrm{a}\end{array}$ & $\begin{array}{l}1816 a \\
2019 b \\
2410 c\end{array}$ & $\begin{array}{l}6463 a \\
6821 a \\
8009 b\end{array}$ & $\begin{array}{l}\mathrm{BCD} \\
\mathrm{ABC} \\
\mathrm{CD}\end{array}$ \\
\hline Westem wheatgrass & $\begin{array}{r}0 \\
56 \\
112 \\
\end{array}$ & $\begin{array}{l}479 a \\
543 a \\
529 a\end{array}$ & $\begin{array}{l}1515 \mathrm{a} \\
1562 \mathrm{a} \\
1611 \mathrm{a}\end{array}$ & $\begin{array}{r}914 \mathrm{a} \\
1203 \mathrm{a} \\
1168 \mathrm{a}\end{array}$ & $\begin{array}{l}1632 \mathrm{a} \\
2203 \mathrm{a} \\
1958 \mathrm{a}\end{array}$ & $\begin{array}{l}4541 \mathrm{a} \\
5511 \mathrm{a} \\
5266 \mathrm{a}\end{array}$ & $\begin{array}{l}\text { A } \\
\text { A } \\
\text { A }\end{array}$ \\
\hline
\end{tabular}

Yield values followed by the same letter within a species and column are not different at $p=0.05$.

${ }^{2}$ Cumulative yield values followed by the same capital letter are not different from other species at the same $N$ rate at $p=0.05$. 
Table 4. Dry matter production in Trial 2 for 10 grass species.

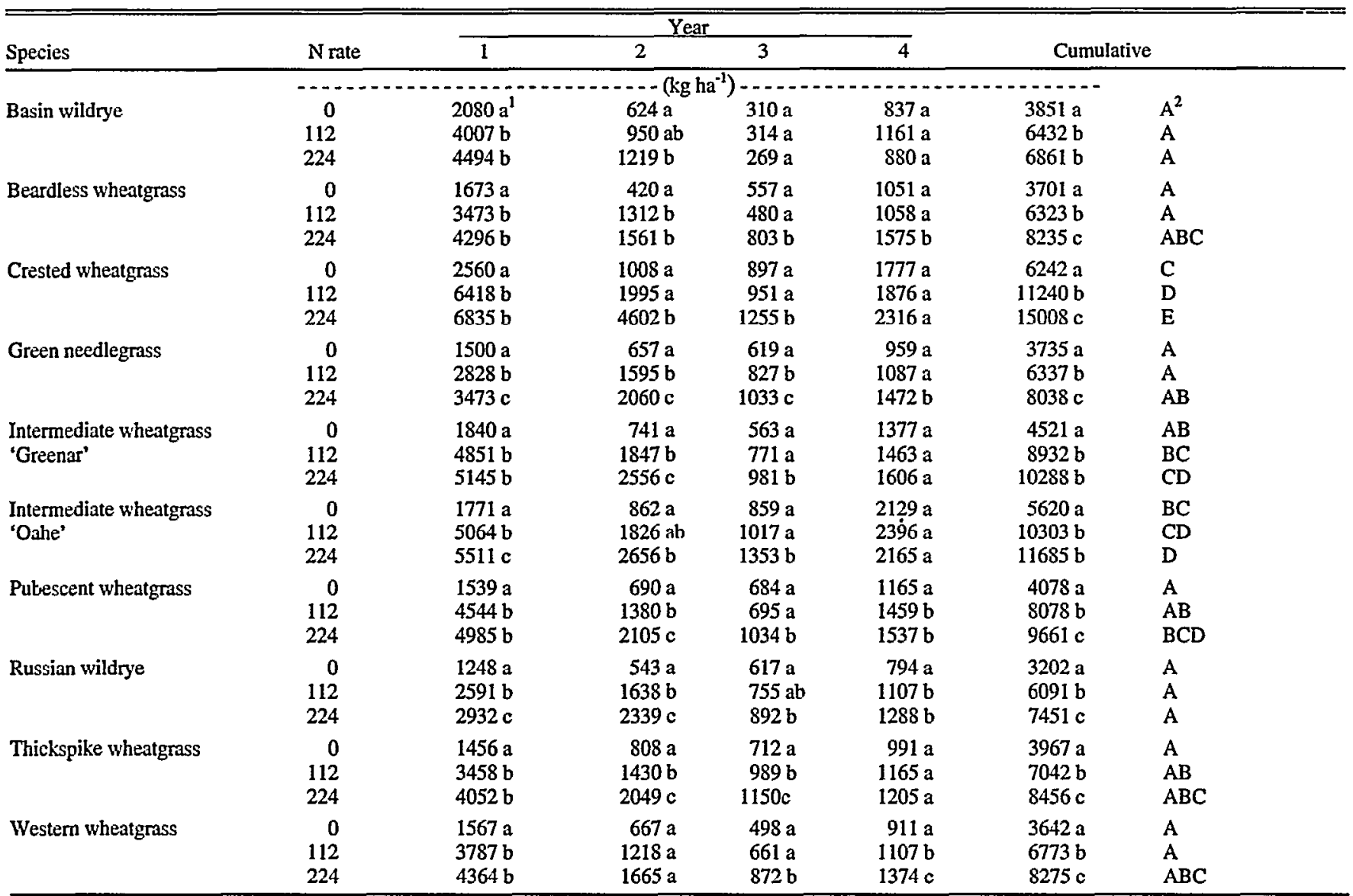

Yield values followed by the same letter within a species and column are not different at $p=0.05$.
2 Cumulative yield values followed by the same capital letter are not different from other species at the same $N$ rate at $p=0.05$.

were applied. Although there was a significant fertilizer response in Trial 1, response was much greater in Trial 2 . Broadcast $\mathbf{N}$ fertilizer is susceptible to positional unavailability, and the drier the conditions, the greater this potential.

Studies by Power (1986) and others have shown that excess N immobilizes in root biomass for future mineralization and plant availability, enters the soil organic fraction through microorganisms, or remains as mineral $\mathrm{N}$ and is not prone to leaching. Since less production increase was noted in Trial 1 and little $\mathrm{N}$ is lost from the system, there is a likelihood that there is a greater $\mathrm{N}$ reserve after Trial 1 compared to Trial 2 . This residual $\mathrm{N}$ would likely be available in years 5 and 6 producing a $\mathrm{N}$ response for some species had the experiment been continued.

\section{Relative N Response by Species}

Variation in yield was observed between species. In Trial 1, 56 $\mathrm{kg} \mathrm{N} \mathrm{ha}{ }^{-1}$ significantly increased 4-year cumulative forage yields over check in 2 out of 10 species ( $p=0.05$, Table 3 ). With $112 \mathrm{~kg}$ $\mathrm{N} \mathrm{ha}{ }^{-1}$, cumulative forage yields for 3 out of 10 species showed a response over the check. The $112 \mathrm{~kg} \mathrm{~N} \mathrm{ha}^{-1}$ application increased forage production over the $56 \mathrm{~kg} \mathrm{~N} \mathrm{ha}^{-1}$ application for only 1 out of 10 species. In Trial 2,112 and $224 \mathrm{~kg} \mathrm{~N}^{-1}$ significantly increased 4-year cumulative forage yields over check in all 10 species ( $\mathrm{p}=0.05$, Table 4). In comparing the $112 \mathrm{~kg} \mathrm{~N}^{-1}{ }^{-1}$ to the $224 \mathrm{~kg} \mathrm{~N} \mathrm{ha}^{-1}$ application, 7 out of 10 species had increased forage production with increased $\mathrm{N}$.
Relative rankings of the 10 species show some consistency from trial to trial, both with and without $\mathrm{N}$ fertilization. The grasses producing greatest amounts of dry matter were 'Oahe' and 'Greenar' intermediate wheatgrasses, crested wheatgrass and pubescent wheatgrass (Tables 3 and 4). The other 6 grasses had smaller responses to $\mathrm{N}$, in particular, beardless wheatgrass and green needlegrass, which had consistently small $\mathrm{N}$ responses. These responses agree with relative production levels found by Kilcher (1958), and Power (1985), with the exception that Power found relatively smaller yields with crested wheatgrass and green needlegrass, and greater yields with western wheatgrass.

A brief economic analysis was conducted using current values ( $\$ 230$ per metric ton $N$ and $\$ 45$ per metric ton hay). A cumulative production increase of $622,1,244$ and $2,488 \mathrm{~kg} \mathrm{ha}^{-1}$ is needed to offset just the fertilizer cost of 56,112 , and $224 \mathrm{~kg} \mathrm{~N} \mathrm{ha}^{-1}$, respectively. In Trial $1,56 \mathrm{~kg} \mathrm{~N}^{-1}$ produced this minimal level in 8 of 10 species, with pubescent wheatgrass returning the most hay per fertilizer dollar, and thickspike wheatgrass the least. At $112 \mathrm{~kg} \mathrm{~N}$ $\mathrm{ha}^{-1}, 7$ of 10 species produced more than the economic break even point, with 'Oahe' intermediate wheatgrass the most economical and western wheatgrass the least. In Trial 2, all 10 species at both fertilization levels produced economic responses, with crested wheatgrass producing the most hay per fertilizer dollar and basin wildrye the least at both $\mathrm{N}$ levels. 
Table 5. Cumulative fertilizer and precipitation use efficiency for 10 grass species over 4 years.

\begin{tabular}{|c|c|c|c|c|c|}
\hline Species & N Rate & \multicolumn{2}{|c|}{ Fertilizer use efficiency } & \multicolumn{2}{|c|}{ Precipitation use efficiency } \\
\hline Beardless wheatgrass & $\begin{array}{r}0 \\
56 \\
112 \\
224\end{array}$ & $\begin{array}{r}11.5 \\
7.0\end{array}$ & $\begin{array}{l}23.4 \\
20.2\end{array}$ & $\begin{array}{l}3.07 \\
3.50 \\
3.59\end{array}$ & $\begin{array}{l}2.89 \\
\\
4.94 \\
6.43\end{array}$ \\
\hline Crested wheatgrass & $\begin{array}{r}0 \\
56 \\
112 \\
224\end{array}$ & $\begin{array}{l}26.1 \\
16.2\end{array}$ & $\begin{array}{l}44.6 \\
39.1\end{array}$ & $\begin{array}{l}4.69 \\
5.68 \\
5.91\end{array}$ & $\begin{array}{c}4.88 \\
\\
8.78 \\
11.7\end{array}$ \\
\hline Green needlegrass & $\begin{array}{r}0 \\
56 \\
112 \\
224\end{array}$ & $\begin{array}{l}8.8 \\
8.9\end{array}$ & $\begin{array}{l}23.2 \\
19.2\end{array}$ & $\begin{array}{l}4.52 \\
4.85 \\
5.19\end{array}$ & $\begin{array}{l}2.92 \\
\\
4.95 \\
6.28\end{array}$ \\
\hline $\begin{array}{l}\text { Intermediate wheatgrass } \\
\text { 'Oahe' }\end{array}$ & $\begin{array}{r}0 \\
56 \\
112 \\
224\end{array}$ & $\begin{array}{l}49.9 \\
31.6\end{array}$ & $\begin{array}{l}41.8 \\
27.1\end{array}$ & $\begin{array}{l}4.94 \\
6.82 \\
7.32\end{array}$ & $\begin{array}{l}4.39 \\
\\
8.05 \\
9.13\end{array}$ \\
\hline Pubescent wheatgrass & $\begin{array}{r}0 \\
56 \\
112 \\
224\end{array}$ & $\begin{array}{l}53.9 \\
20.7\end{array}$ & $\begin{array}{l}35.7 \\
24.9\end{array}$ & $\begin{array}{l}4.07 \\
6.10 \\
5.63\end{array}$ & $\begin{array}{l}3.19 \\
\\
6.31 \\
7.55\end{array}$ \\
\hline Russian wildrye & $\begin{array}{r}0 \\
56 \\
112 \\
224\end{array}$ & $\begin{array}{l}21.3 \\
11.8\end{array}$ & $\begin{array}{l}25.8 \\
19.0\end{array}$ & $\begin{array}{l}3.22 \\
4.02 \\
4.11\end{array}$ & $\begin{array}{l}2.50 \\
\\
4.76 \\
5.82\end{array}$ \\
\hline Average & $\begin{array}{r}0 \\
56 \\
112 \\
224\end{array}$ & $\begin{array}{l}23.9 \\
14.8\end{array}$ & $\begin{array}{l}31.2 \\
22.9\end{array}$ & $\begin{array}{l}4.06 \\
4.96 \\
5.17\end{array}$ & $\begin{array}{l}3.33 \\
\\
6.06 \\
7.34\end{array}$ \\
\hline
\end{tabular}

\section{Fertilizer Use Efficiency}

From data on fertilizer rate and grass production greater than check, a fertilizer use efficiency (FUE) was calculated as $\mathrm{kg}$ cumulative dry matter per $\mathrm{kg}$ applied $\mathrm{N}$ (Table 5). In Trial 1, 56 $\mathrm{kg} \mathrm{N} \mathrm{ha}{ }^{-1}$ was more efficient than $112 \mathrm{~kg} \mathrm{~N}^{-4}$ for 8 out of 10 species. Pubescent wheatgrass and 'Oahe' intermediate wheatgrass produced the most forage per $\mathrm{kg}$ applied $\mathrm{N}$ with $56 \mathrm{~kg} \mathrm{~N}$ $\mathrm{ha}^{-1}$ (53.9 and $49.9 \mathrm{~kg} \mathrm{~kg} \mathrm{~N}^{-1}$ ), while thickspike wheatgrass and green needlegrass produced the least $\left(6.4\right.$ and $\left.8.8 \mathrm{~kg} \mathrm{~kg} \mathrm{~N}^{-1}\right)$. At $112 \mathrm{~kg} \mathrm{~N} \mathrm{ha}{ }^{-1}$, 'Oahe' intermediate wheatgrass, pubescent wheatgrass, and 'Greenar' intermediate wheatgrass had the greatest FUE $\left(31.6,20.7\right.$, and $20.0 \mathrm{~kg} \mathrm{~kg} \mathrm{~N}^{-1}$, respectively), while western wheatgrass, and beardless wheatgrass had the least FUE ( 6.5 and $7.0 \mathrm{~kg} \mathrm{~kg} \mathrm{~N}^{-1}$ ).

In Trial $2,112 \mathrm{~kg} \mathrm{~N}^{-1}$ produced a more efficient response than $224 \mathrm{~kg} \mathrm{~N} \mathrm{ha}{ }^{-1}$, for all species. At $112 \mathrm{~kg} \mathrm{~N} \mathrm{ha}^{-1}$, crested wheatgrass and 'Oahe' intermediate wheatgrass had the greatest fertilizer use efficiency (FUE) ( 44.6 and $41.8 \mathrm{~kg} \mathrm{~kg} \mathrm{~N}^{-1}$ ). Basin wildrye, green needlegrass and beardless wheatgrass had the smallest FUE $\left(23.1,23.2\right.$, and $\left.23.4 \mathrm{~kg} \mathrm{~kg} \mathrm{~N}^{-1}\right)$. At the $224 \mathrm{~kg} \mathrm{~N}$ ha $^{-1}$ rate, basin wildrye had the least FUE with $13.4 \mathrm{~kg} \mathrm{~kg} \mathrm{~N}^{-1}$, while crested wheatgrass had the greatest at $39.1 \mathrm{~kg} \mathrm{~kg} \mathrm{~N}^{-1}$.

In both trials, an increased fertilizer ratc resulted in decreased efficiency, consistent with Wight (1976). McGinnies (1968) had similar findings for annual applications of $\mathrm{N}$ to old stands of crested wheatgrass [Agropyron desertorum (Fisch. ex Link) Schult.], but when a single $\mathrm{N}$ application was made, maximum efficiency was reached at 67 to $112 \mathrm{~kg} \mathrm{~N} \mathrm{ha}^{-1}$, with decreased efficiency at larger and smaller rates. The fertilizer use efficiency decrease with larger $\mathrm{N}$ rates is partly explained by limited water. It is more likely for the $\mathrm{N}$ to be used at smaller fertilization rates than at greater rates, in a given season. With larger $N$ applica- 
tions, all the available water will be used before all the $\mathrm{N}$ has contributed to growth. Another factor is that greater soil N levels contribute to higher $\mathrm{N}$ content in grass tissue. Reductions in efficiencies with smaller $\mathrm{N}$ applications were not seen in this study, but McGinnies (1968) tested smaller $N$ rates, and found that over several years, very little fertilizer response was seen. The grasses of Trial 2 converted applied $N$ to dry matter 1.3 to 4.3 times more efficiently than in Trial 1, apparently related to the improved growing conditions, and indicates that different results can occur due to variation in precipitation. Growing conditions during the year of application is particularly critical. In drier years, less fertilizer $\mathrm{N}$ is utilized and more is immobilized in grass roots and soil organic matter. This immobilized $\mathbf{N}$ is only slowly available over the following years.

\section{Precipitation Use Efficiency}

Precipitation use efficiency (PUE) can also be used to evaluate $\mathrm{N}$ response of grass species in different environments. A PUE was calculated for each trial from cumulative dry matter production divided by $\mathrm{mm}$ of precipitation from 1 October after planting through 30 September of the last sample year.

One reason Trial 1 and Trial 2 had different yields was due to different precipitation patterns during the 2 periods. Because cumulative available water was constant within each trial, PUE within a trial points out the same numerical relationships that are present in dry matter response. Nevertheless, like Power (1980) and Wight and Black (1972), this study showed increasing PUE with increasing fertilizer rates. Grasses with increased production had better PUE levels. A reasonable linear response was found between $N$ rate and PUE for Trial $1(r=0.41, p=0.05)$ and Trial $2(r=0.76, p=0.01)$. Despite differing climatic responses to applied $\mathrm{N}$, we found a good linear relationship with both trials (PUE $=0.016 \mathrm{~N}$-rate $+3.79, \mathrm{r}=0.71, \mathrm{p}=0.01$ ).

\section{Conclusion}

Dryland grass production can be increased by $\mathrm{N}$ fertilization. Applied $\mathrm{N}$ was used more effectively by grasses when the growing season was more conducive to growth. However, during particularly dry seasons, much of the fertilizer $\mathrm{N}$ does not result in increased yield, but according to the literature, and supported by this study, remains unused mainly as organic $\mathrm{N}$ in the root system and soil for subsequent years. This one time application of $\mathrm{N}$ could have also enhanced the vigor of the grasses by drastically increasing root growth and storage of $\mathrm{N}$ in roots, thereby increasing potentially mineralizable $\mathrm{N}$ in the soil and increasing production through at least the following 4 years (Smith and Power 1985, Power 1986). Different grasses have differing yield potentials and response potential to $\mathrm{N}$ fertilization, as well as other growth and forage quality characteristics. This study found crested wheatgrass, 'Greenar' and 'Oahe' intermediate wheatgrasses and pubescent wheatgrass to consistently rank above 6 other grasses in our trials under different environmental cycles. Economically, these grasses are most likely to give increased hay value for every fertilizer dollar invested.

\section{Literature Cited}

Black, A.L. 1968. Nitrogen and phosphorus fertilization for production of crested wheatgrass and native grass in northeastern Montana. Agron J. 60:213-216.

Caprio, J.M., D.I. Cooksey, J.S. Jacobsen, G.A. Nielsen, and R.R. Roche. 1994. MAPS Atlas-A land and climate information system. EB125. Montana State Univ., Bozeman.

Daugherty, A.B. 1991. Major uses of land in the United States: 1987. U.S. Dept. Ag. Economic Research Service. Agr. Econ. Rep. Number 643.

Johnston, A., S. Smoliak, A.D. Smith and L.E. Lutwick. 1969. Seasonal precipitation, evaporation, soil moisture, and yield of fertilized range vegetation. Can. J. Plant Sci. 49:123-128.

Kilcher, M.R. 1958. Fertilizer effects on hay production of three cultivated grasses in southern Saskatchewan. J. Range Manage. 11:231-234.

Lutwick, L.E. and A.D. Smith. 1979. Yield and N uptake by seven perennial grass species as affected by high rates of $\mathbf{N}$ fertilizer. $J$. Range Manage. 32:433-436.

Mason, J.L. and J.E. Miltimore. 1972. Ten year yield response of beardless wheatgrass from a single nitrogen application. J. Range Manage. 25:269-272.

McGinnies, W.J. 1968. Effects of nitrogen fertilization on an old stand of crested wheatgrass. Agron. J. 60:560-562.

Power, J.F. 1980. Response of semiarid grassland sites to nitrogen fertilization: I. Plant growth and water use. Soil Sci. Soc. Amer. J. 44: 545-550.

Power, J.F. 1985. Nitrogen- and water-use efficiency of several coolseason grasses receiving ammonium nitrate for 9 years. Agron. J. 77:189-192.

Power, J.F. 1986. Nitrogen cycling in seven cool-season perennial grass species. Agron. J. 78:681-687.

Power, J.F. and J. Alessi. 1971. Nitrogen fertilization of semiarid grasslands: Plant growth and soil mineral N levels. Agron. J. 63:277-280.

Read, D.W.L. and G.E. Winkleman. 1982. Residual effects of nitrogen and phosphorus fertilizer on crested wheatgrass under semiarid conditions. Can. J. Plant Sci. 62:415-425.

Smith, S.J. and J.F. Power. 1985. Residual forms of fertilizer nitrogen in a grassland soil. Soil Sci. 140:362-367.

Snedecor, G.W. and W.G. Cochran. 1980. Statistical Methods. Iowa State Univ. Press. 507 p.

Wight, J.R. 1976. Range fertilization in the Northern Great Plains. J. Range Manage. 29:180-185.

Wight, J.R. and A.L. Black. 1972. Energy fixation and precipitation-use efficiency in a fertilized rangeland ecosystem of the Northern Great Plains. J. Range Manage. 25:376-380.

Wight, J.R. and A.L. Black. 1979. Range fertilization: Plant response and water use. J. Range Manage. 32:345-349. 